\title{
Nitrogen compounds and volatile fatty acids absorption from the caecum and colon of sheep
}

\author{
Beata Skiba, J. Kowalczyk and Teresa Żebrowska
}

\author{
The Kielanowski Institute of Animal Physiology and Nutrition, \\ Polish Academy of Sciences \\ 05-110 Jablonna, Poland
}

(Received to August 1995; accepted 12 January 1996)

\begin{abstract}
Four rams provided with a permanently isolated of $250 \mathrm{ml}$ capacity caecum and another 4 with an isolated $1 \mathrm{~m}$ long loop colon were used in this study. The isolated caecum was filled and colon perfused with solutions of differing urea concentrations $(0.01 ; 0.015 ; 0.02 \%)$ or VFA and ammonia concentrations ( 43 and $91 \mathrm{mM}$ or 50 and $100 \mathrm{mM}$ ). The caecum pouch was filled with a solution of $0.1,0.15$ or $0.3 \%$ enzymatic casein hydrolysate.

Urea was not absorbed from the caecum or colon, regardless of its concentration in the solution. The fractional absorption rate of VFA in the caecum was higher $(58 \%)$ than in the colon $(38 \%)$. The rate of absorption of butyric acid was highest, and acetic acid lowest, irrespective of the VFA concentration in the solution. Increasing the VFA concentration administered in solution had a significant effect only on the amount of acetic acid absorbed from the caecum and colon $(P \leqslant 0.01$ and $P \leqslant 0.05$, respectivcly).

Only the net disappearance of aspartic and glutamic acids, threonine and serine from the enzymatic casein hydrolysate in the caccum was significant, but increasing the concentration of amino acids in the solutions did not have a significant effect on their rate of absorption.
\end{abstract}

KEY WORDS: sheep, absorption, amino acids, urea, VFA, caecum, colon

\section{INTRODUCTION}

There is evidence that substantial quantites of microbial and feed protein are digested in the large intestine and that nitrogen is absorbed predominantly in the form of ammonia (Żebrowska, 1975; Dixon and Nolan, 1982; Schmitz et al., 1991; Bochroder et al., 1994). Some reports show that amino acids can be absorbed from the caecum of pigs and mice (Robinson et al., 1973; Olszcwski, 
1975; James and Smith, 1976; Jarvis et all., 1977), but data is lacking on the absorption of amino acids from the large intestine of sheep. Volatile fatty acids appear in the large intestine digesta, as the products of carbohydrate fermentation, in proportions similar to those found in the rumen (Ørskov, 1970; Owens and Goetsch, 1988) and 65 to $95 \%$ of them are absorbed from the ceacum and colon.

The aim of the present study was to measure the extent of ammonia, urea, amino acids and VFA absorption from the isolated caecum and colon of sheep.

\section{MATERIAL AND METHODS}

\section{Animals and feeding}

The experiment was carried out on 8 one-year-old rams of about $45 \mathrm{~kg}$ body weight. Four of them were provided with permanently isolated caecum pouches and 4 with $1 \mathrm{~m}$ long loops of colon which were washed with $0.9 \% \mathrm{NaCl}$ solutions containing antibiotics as described in previous paper (Skiba et al., 1995). The animals were given diet consisting of $700 \mathrm{~g}$ of meadow hay and $400 \mathrm{~g}$ of barley with mineral mixture supplement containing ( $\%$ of DM): OM - 94.7; $\mathrm{CP}-11.1$; crude fibre -24.8 ; ether extract -2.4 and NFE - 56.4). Daily rations were distributed over two equal meals at 8 and $15 \mathrm{~h}$ and given for at least two weeks before the experiment started.

\section{Solutions}

The following solutions containing 2 g/ 1 PEG 4000 were used: - urea solution $-0.01,0.015$ and $0.02 \%$

- VFA mixture (molar proportion of C2 - 60\%, C3 - 25\% and C4 $-15 \%$, partly neutralized with ammonium) contained:

a. $43 \mathrm{mM}$ VFA and $12 \mathrm{mM}$ ammonia or $91 \mathrm{mM}$ VFA and $16 \mathrm{mM}$ ammonia use to measure their absorption from the caecum pouch

b. $50 \mathrm{mM}$ VFA and $10.3 \mathrm{mM}$ ammonia or $100 \mathrm{mM}$ VFA and $20.7 \mathrm{mM}$ ammonia, used to measure absorption from the colon loop,

- free amino acids as $0.1,0.15$ and $0.30 \%$ casein enzymatic hydrolysates used to measure free amino acids absorption from the caecum pouch.

\section{Experimental design}

To study the absorption of nitrogenous compounds and VFA the isolated caecum and colon were filled or perfused with each of experimental solutions. The experiments started after the morning meal and were repeated for 5 days. 
Urea, ammonia and VFA absorption was measured in both caecum and colon while the amino acids absorption was estimated only in the caecum.

The isolated pouch of the caecum was filled with $250 \mathrm{ml}$ of experimental solutions and samples of $20 \mathrm{ml}$ were withdrawn at 2 and $4 \mathrm{~h}$ afterwards. The isolated colon loop was perfused with experimental solutions by means of a peristaltic pump at a rate of $5 \mathrm{ml} / \mathrm{min}$ for $5 \mathrm{~h}$. The perfusate, collected in the bottle kept on ice during the last $4 \mathrm{~h}$ of perfusion, was measured and sampled. The perfusion procedure was repeated for 5 days. All samples were stored deep frozen for analysis.

\section{Analysis}

Total nitrogen, protein- $\mathrm{N}$, urea-N, ammonia- $\mathrm{N}$ and PEG were measured as reported in a previous paper (Skiba et al., 1995). Samples for VFA assay were acidified with $0.1 \mathrm{ml} 85 \%$ formic acid per $1 \mathrm{ml}$ of sample and kept at $-18^{\circ} \mathrm{C}$ until analyzed for VFA according Ziołecki and Kwiatkowska (1973) using Philips PU 4410 gas chromatography equipment. Samples for amino acids determination were deproteinized with sulphosalicylic acid and analyzed with amino acid analyzer T 339.

\section{Statistical analysis}

Statistical analysis was carried out by single variable variance analysis and of Tuckey test using Statgraphics Software, wersion 7.0.

\section{RESULTS}

\section{Urea and ammonia absorption}

The results given in Tables 1 and 2 show that there was not net absorption of urea in the caecum and colon. The amount of urea-N estimated in the caecum pouch increased with time independent of the urea concentration in the

The amount of urea-N $(\mathrm{mg} / 250 \mathrm{ml})$ introduced into the caecum and found after 2 and $4 \mathrm{~h}$ $($ mean $\pm S D ; n=4)$

\begin{tabular}{lccc}
\hline \multirow{2}{*}{ Urea-N $(\mathrm{mg} / 250 \mathrm{ml})$} & \multicolumn{3}{c}{ Urea concentration in the solution, \%, $(\mathrm{mmol})$} \\
\cline { 2 - 4 } & $0.01 \%(7.0)$ & $0.015 \%(10.0)$ & $0.02 \%(14.0)$ \\
\hline Introduced to the caecum & $22.2 \pm 0.5^{\mathrm{a}}$ & $33.9 \pm 0.5^{\mathrm{a}}$ & $42.9 \pm 1.3^{\mathrm{a}}$ \\
Estimated in the caecum after $2 \mathrm{~h}$ & $23.1 \pm 1.1^{\mathrm{ab}}$ & $34.9 \pm 1.3^{\mathrm{ab}}$ & $44.8 \pm 1.5^{\mathrm{ab}}$ \\
Estimated in the caecum after $4 \mathrm{~h}$ & $24.2 \pm 1.7^{\mathrm{b}}$ & $36.1 \pm 1.2^{\mathrm{b}}$ & $46.0 \pm 1.8^{\mathrm{b}}$ \\
\hline
\end{tabular}

in colums: $\mathrm{a}, \mathrm{b}-\mathrm{P} \leqslant 0.05$ 
TABLE 2

The amount of urea- $\mathrm{N}(\mathrm{mg} / \mathrm{m} / \mathrm{h})$ introduced and estimated in the liquid leaving the isolated colon (mcan $\pm \mathrm{SD} ; \mathrm{n}=4$ )

\begin{tabular}{llccc}
\hline \multirow{2}{*}{ Hours } & & \multicolumn{3}{c}{ Urea concentration in the solution } \\
\cline { 3 - 5 } & & $0.01 \%(7.0 \mathrm{mmol})$ & $0.015 \%(10.0 \mathrm{mmol})$ & $0.02 \%(14.0 \mathrm{mmol})$ \\
\hline 1 & introduced & $27.8 \pm 2.6^{\mathrm{a}}$ & $38.8 \pm 3.1^{\mathrm{a}}$ & $49.5 \pm 4.3^{\mathrm{a}}$ \\
& found & $21.9 \pm 3.5^{\mathrm{b}}$ & $26.8 \pm 3.6^{\mathrm{b}}$ & $37.3 \pm 6.5^{\mathrm{b}}$ \\
2 & introduced & $27.5 \pm 3.0^{\mathrm{a}}$ & $38.1 \pm 1.1^{\mathrm{a}}$ & $52.1 \pm 4.3^{\mathrm{a}}$ \\
& found & $28.1 \pm 3.5^{\mathrm{a}}$ & $39.5 \pm 2.0^{\mathrm{a}}$ & $53.4 \pm 4.1^{\mathrm{a}}$ \\
3 & introduced & $26.8 \pm 1.7$ & $37.1 \pm 2.4$ & $50.8 \pm 4.3$ \\
& found & $27.1 \pm 2.2$ & $37.9 \pm 2.4$ & $51.5 \pm 4.3$ \\
4 & introduced & $26.2 \pm 1.6$ & $39.8 \pm 3.2$ & $51.6 \pm 4.4$ \\
& found & $25.6 \pm 2.1$ & $40.7 \pm 3.2$ & $53.9 \pm 5.2$ \\
5 & introduced & $26.8 \pm 1.7$ & $37.9 \pm 2.4$ & $47.9 \pm 2.7$ \\
& found & $25.8 \pm 1.7$ & $36.9 \pm 2.5$ & $49.2 \pm 4.0$ \\
mean $^{\mathrm{x}}$ & introduced & 26.8 & 38.2 & 50.6 \\
& found & 26.8 & 38.7 & 52.0 \\
\hline
\end{tabular}

- mean without $\mathrm{l} \mathrm{h}$

$a, b-P \leqslant 0.05$ differences between introduced and found amounts

administered solution ( $\mathrm{P}<0.05$ after $4 \mathrm{~h}$ ) (Table 1 ). The amount of urea-N introduced into the isolated colon loop was similar to the amount leaving the colon loop (Table 2).

Ammonia was absorbed effectively from the isolated caccum and colon (Table 3). Net absorption of ammonia from the caecum at both concentrations equaled $2.2 \mathrm{mM}$, but when expressed as a relative percentage of the amount introduced, ammonia absorption was lower at higher concentrations (73 and $55 \%$ ). The amount of absorbed ammonia in the colon was smaller at lower concentrations $(1.74$ vs. $4.35, \mathrm{P}<0.01)$ but similar when expressed as a relative percentage of the introduced (14 vs. $18 \%$ ).

\section{Volatile fatty acid absorption}

The amount of total, acetic, propionic and butyric acids absorbed was greater $(P<0.05)$ from the solution with the higher $V F \Lambda$ concentrations (Table 3 ). The absorption rate expressed as a percentage of total and individual acids was higher in the caecum $(49-79 \%)$ than in the colon $(26-56 \%)$. The fractional absorption rates of VFA from the caecum and colon were in the following order: butyrate $>$ propionate $>$ acetate. The rate of absorption of these acids from the 
㩊

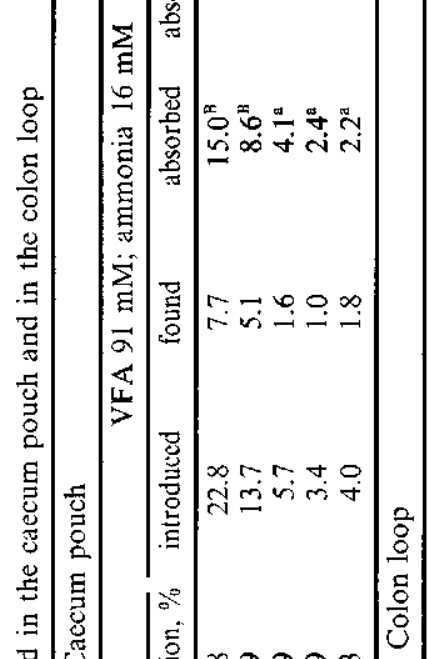

离

:

守

岁

몽

용

马ु్

몬

豆

:

急

귤

$\frac{4}{3}$

岁

菃

官

勿

荡

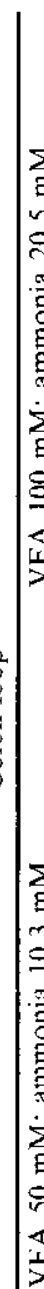
舟

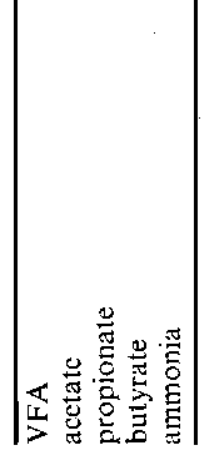

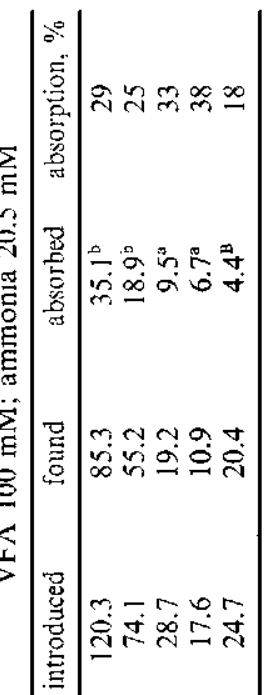

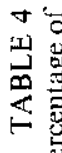

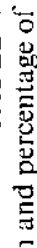

(

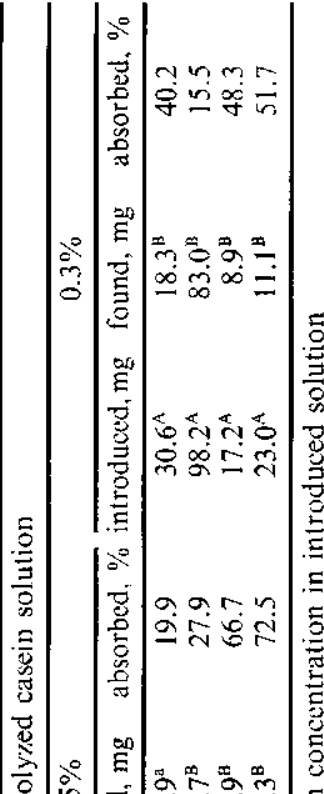

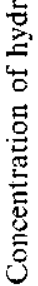

落

-m

总

范

获

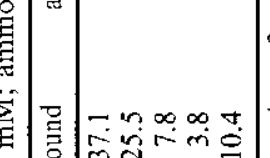

穴

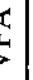

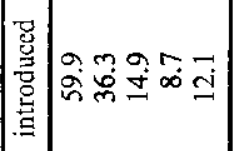

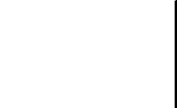

$-\pi$

|

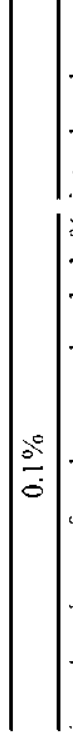

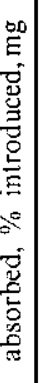

0 in $\infty$

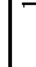

2000

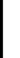

Е

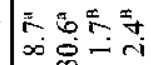

$\frac{\sqrt{2}}{\sqrt[2]{2}}$

을

它

5
동ํㅇㅇㅇ 
colon was lower than from the caecum, and butyrate and propionate had also higher rates of absorption than acetate.

\section{Amino acid absorption from the caecum}

Table 4 shows the amount of some amino acids introduced into the caecum and found after incubation in the caecum pouch. Among 16 amino acids assayed, only Asp (19-40\%), Glu (28\%), Thr (48-73\%) and Ser (30-52\%) were absorbed from the isolated caccum in significant after $4 \mathrm{~h}$. Changes in the amount of other amino acids were small and insignificant. The concentration of amino acids in the experimental solution had no effect on their absorption rate (Table 4).

\section{DISCUSSION}

Results of this study show that urea was not absorbed from the isolated caecum and colon of sheep. Under physiological conditions, urea entering the large intestine is rapidly hydrolyzed to ammonia by bacterial urease, therefore it is possible that ability of the large intestinal epithelium to absorb urea did not develop. Data found in the literature concern only disappearance of urea from the large intestine after its degradation to ammonia (Hogan, 1961; Nolan and Leng, 1972; Dixon and Nolan, 1982).

Net absorption of ammonia from the isolated colon rose with increased ammonia concentration at both concentration indicating that the colon has a high absorptive potential of ammonia. Net absorption of ammonia in the caecum was $2.2 \mathrm{mmol}$ at both concentrations, demonstrating that both already exceeded the absorptive potential of ammonia from the caecum.

The concentration of total VFA and the relationship between proportion of individual VFA in the rumen and large intestine depends on the amount and composition of the diet fed, but mainly on the type and amount of carbohydrate in the diet (Murphy et al., 1982; Sutton, 1985). The molar proportion of acetate in the rumen or large intestine digesta rise with increasing amount of roughages in the diet (Parks et al., 1964) when the total VFA concentration is usually higher as the amount readily fermented carbohydrate.

According to Ørskov et al. (1970) the proportions of individual VFA in the caecum content of sheep are similar with these in the rumen. In our experiments absorption of VFA from the solutions of 43 and $91 \mathrm{mM} / 1$ in the caecum or 50 and $100 \mathrm{mM} / 1$ in the colon were estimated. The molar proportions of acetic, propionic and butyric acids were 60:25:15, close to the values often met in the rumen of animals fed rations containing high proportion of roughages (Owens and Goetsch, 1980). 
Contrary to the results of Masson and Phillipson (1951), and Hogan (1961), in the present study the effect of VFA concentration on individual fractional absorption from the caecum and colon was not clear; only absorption of acetic acid depended significantly on the VFA concentration. These results are in agreement with Dijkstra et al. (1993) who showed that absorption of individual VFA not always corresponds to their rumen concentration.

In the present study the absorption of VFA from the caecum of sheep $(58-66 \%)$ was lower than values found in rabbits $(65-95 \%)$ (Leng, 1978). This differences could be caused by differences between species or higher concentration of butyric acid (22\%) in the study of Leng (1978) than in our study (15\%). The intensity of the acetate $(30-25 \%)$, propionate $(47-33 \%)$ and butyrate (57-38\%) absorption from the colon decreased with increasing VFA concentration and was less than our values for the caecum and results of Argenzio et al. (1975) obtained for the colon of goats $(95 \%$ of the acetate and propionate was absorbed).

A coefficient of the relative fractional rate of individual VFA absorption in relation to acetic acid absorption may be expressed more precisely by the method of Weigand et al. (1972) in which the number of mmols of acid absorbed is divided by the number of mmols in the initial fluid and this results is divided by the fractional rate of acetic acid absorption. Thus, the coefficient of the relative rate of absorption for acetic acid by definition is 1 . The highest relative fractional absorption rate coefficient in the caecum was for butyric acid, 1.83; for propionate this value was lower -1.55 and acetic acid was -1.0 . The specific absorption rates of VFA in the colon were lower than in the caecum but of the same order of magnitude. Comparable results were presented by Weigand et al. (1972) in a study on calves; specific absorption rate coefficients for acetate, propionate and butyrate were $1.0 ; 1.45$ and 1.84 , respectively. This also corresponds with studies by Kowalczyk et al. (1971), Hoover and Heitmann (1972), Thorlacius and Lodge (1973) and Dijkstra et al. (1993) who studied rates of individual VFA absorption from the rumen suggesting that the processes of VFA absorption from the caecum resemble those in the rumen, but VFA absorption from the colon tended to be lower than in the rumen and caecum.

Amino acid absorption from the caecum has not been studied intensively and data avilable are often divergent. Bochroder et al. (1994) reported that the colon epithelium of the horse is not permeable for histidine, lysine and arginine. Schmitz et al. (1991) found arginine absorption from the caecum of cow, pig and horse below $10 \%$. Olszewski showed that only threonine and serine were absorbed from the amino acid mixture introduced into the isolated caecum pouch of pigs. According to Darragh et al. (1994) free lysine and methionine were not absorbed in nutritionally significant amounts infused into the colon of the 15-32 d old piglets. Binder (1970) and Hoover and Heitmann (1975) found that 
alanine and glycine were absorbed from the colon of rabbits but they were not from the colon of sheep. Our experiment demonstrated significant net absorption of some amino acids from enzymatically hydrolyzed casein introduced into the isolated caecum of sheep: threonine $(48-73 \%)$, serine $(30-52 \%)$, arginine (7-31\%), aspartic acid (19-40\%) and glutamic acid (11-28\%) while the disappearance of remaining amino acids was insignificant.

Despite of data indicating possibility of transporting some amino acids across the colon epithelium the mechanism of that is unclear. Binder (1970) suggested that alanine and glycine are absorbed through simple diffusion as increasing amino acid concentrations provokes a linear increase of transport across the colon epithelium. However, the results of our experiment indicate that increased amino acid concentration not always caused increased absorption. The presence of glucose (Olszewski, 1975) or sodium and potassium ions (Robinson et al., 1973; Lind et al., 1980; Munck, 1981) were found to play important role in the absorption of some amino acids from the caecum or colon of sheep, dog or chicken. Such data support the active or facilitated character of the absorption process.

The above results suggest that, irrespective of the animal species, some amino acids can be absorbed from the large intestine and that the active absorption may be involved in this process similarly as in the small intestine. This is, however, nutritionally insigificant because of relatively small amounts of free amino acids entering the large intestine and high deaminative activity of bacteria.

\section{REFERENCES}

Binder I1.J., 1970. Amino acids absorption in the mammalian colon. Biochim. Biophys. Acta. 219, 503-506

Bochroder B., Schubert R., Bodeker D., 1994. Studies on the transport in vitro of lysine, histidine, arginine and ammonia across the mucosa of the equine colon. Equine Vet. 26, 131-133

Darragh A.J., Cranwell P.D., Moughan P.J., 1994. Absorption of lysine and methionine from the proximal colon of the piglet. Brit. J. Nutr. 71, 739-753

Dijkstra J., Boer H., Van Bruchem J., Bruining M., Tamminga S., 1993. Absorption of volatile fatty acids from the rumen of lactating dairy cows as influenced by volatile fatty acids concentration, $\mathrm{pH}$ and rumen liquid volume. Brit. J. Nutr. 69, 385-396

Dijkstra J., 1994. Production and absorption of volatile fatty acids in the rumen. Livest. Prod. Sci. 39, 61-69

Dixon R.M., Nolan J.V., 1982. Studies of the large intestine of sheep. Fermentation and absorption in sections of the large intestine. Brit. J. Nutr. 47, 289-300

Hogan J.P., 1961. The absorption of ammonia through the rumen of the sheep. Aust. J. Biol. Sci. 14, $448-460$ 
Hoover W.H., Heitmann R.N., 1972. Effects of dictary fiber levels on weight gain, caecal volume and volatile falty acid production in rabbits. J. Nutr. 102, 375-380

James P.S., Smith M.W., 1976. Methionine transport by pig colonic mucosa measured during early post-natal development. J. Physiol. 262, 151-168

Jarvis L.G., Morgan G., Smith M.W., Wooding F.B.P., 1977. Cell replacement and changing transport function in the neonatal pig colon. J. Physiol. 273, 717-729

Kowalczyk J., Ramirez A., Geerken C.M., 1971. Nitrogen and carbohydrate metabolism in rumen and duodenum of young bulls given diets based on molasses/urea. Rev. Cubana Cienc. Agric. (Eng. ed.) 5, 21-26

Leng F., 1978. Absorption of inorganic ions and volatile fatty acids in the rabbit caecum. Brit. J. Nutr. 40, 509-519

Lind J., Munck B.G., Olsen O, 1980. Effects of dietary intake of sodium chloride on sugar and amino acid transport across isolated hen colon. J. Physiol. 305, 327-336

Masson M.J., Phillipson A.T., 1951. The absorption of acetate, propionate and butyrate from the rumen of sheep. J. Physiol. 113, 189-206

Munck B.G., 1981. Intestinal absorption of amino acids. In: L.R. Johnson (Editor), Physiology of the gastrointestinal tract. Raven Press Books, New York, Vol. 2. pp. 1097-1123

Murphy M.R., Baldwin R.L., Koong L.J., 1982. Estimation of stoichiometric parameters for rumen fermentation of roughage and concentrate dicts. J. Anim. Sci. 55, 411-421

Nolan J.V., Leng R.A., 1972. Dynamic aspects of ammonia and urea metabolism in shecp. Brit. J. Nutr. 27, 177-194

Olszewski A., 1975. Absorption of amino acids in the caecum of pig. PhD Thesis, Institute of Animal Physiology and Nutrition, Jabłonna, Poland

Ørskov E.R., Fraser C., Mason V.C., Mann S.O., 1970. Influence of starch digestion in the large intestine of sheep on caecal fermentation, caecal microflora and faccal nitrogen excretion. Brit. J. Nutr. 24, 671-682

Owens F.N., Goetsch A.L.. 1988. Ruminal fermentation. In: D.C. Church (Editor), Digestive physiology and nutrition, pp. 145-171

Parks P.F., Riewe M.E., Lyman C.M., Kunkel H.O., 1964. Variations in the intraruminal fatty acids ration in sheep fed reygrass harvestcd at different stages of maturity. J. Anim. Sci. 23, 344-349

Robinson J.W.L., Luisier A.L., Mirkovitch V., 1973. Transport of amino acids and sugars by dog colonic mucosa. Pflügers-Archiv 345, 317-326

Schmitz M., Ahrens F., Schon J., Hagemeister H., 1991. Amino acids absorption in the large intestine of cows, pigs and horses and its significance for protein supply. Advan. Anim. Physiol. Anim. Nutr. 22, 67-71

Skiba B., Kowalczyk J., Żebrowska T., 1995. Secretion of nitrogen compounds into the isolated caecum and colon of shecp. J. Anim. Feed Sci. 4, 321-331

Sutton J.D., 1985. Digestion and absorption of energy substrates in the lactating cow. J. Dairy Sci. $68,3376-3393$

Thorlacius S.O., Lodge G.A., 1973. $\Lambda$ bsorption of steam-volatile fatty acids from the rumen of the cow as influcneed by dict, buffers and pH. Can. J. Anim. Sci. 53, 279-288

Weigand E., Young J.W., McGillard A.D., 1972. Extent of butyrate metabolism by bovine ruminoreticulum epithelium and the relationship to absorption ratc. J. Dairy Sci. 55, 589-597

Ziołecki $\Lambda$., Kwiatkowska E., 1973. Gas chromatography of $\mathrm{C}_{1}$ to $\mathrm{C}_{s}$ fatty acid in rumen fluid and fermentation media. J. Chromatogr. 80, 250-254

Żebrowska T., 1975. The apparent digestibility of nitrogen and individual amino acids in the large intestine of pigs. Rocz. Nauk rol. 97, 117-122

Żebrowska T., 1978. Apparent digestibility of nitrogen and amino acids and utilization of protcin given orally or introduced into the large intestine of pigs. Roc\%. Nauk rol. Ser. B, 99, 99-104 


\section{STRESZCZENIE}

Wchlanianie związków azotowych i LKT z jelita ślepego i okrężnicy u owiec

Doświadczenia przeprowadzono na 4 ıryczkach z wyizolowanym jelitem ślepym z kaniulą oraz na 4 tryczkach $z$ wyizolowaną częśsią okrężnicy. Izolowane jelito ślepe wypelniano, a okrężnicę przcpłukiwano roztorami mocznika o stężeniu 0,$01 ; 0,15 ; 0.02 \%$ oraz roztworami różniącymi się stężeniem VFA - 43 i $91 \mathrm{mM}$ oraz 50 i $100 \mathrm{mM}$. Jelito ślepe wypelniano także roztworem hydroli-

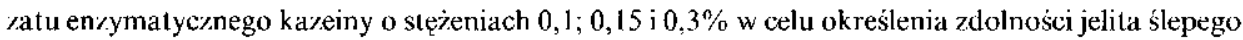
do wchłaniania aminokwasów.

Mocznik w podawanych roztworach, niczależnie od jego stężenia, nic uległ wchłanianiu z jelita ślepego i okrężnicy. Intensywność wchłaniania LKT z izolowanego jelita ślepego była większa (58\%) niż z pętli okrężnicy (38\%). Tempo wchlaniania kwasu maslowego było największe, a octowego najmniejsze, niezależnie od stężenia LKT w podawanym roztworze. Ilość wchloniętego z jelita ślcpego i okrężnicy kwasu octowego zależała istotnie $(P \leqslant 0,01$ i $\mathrm{P} \leqslant 0,05$, odpowiednio) od stężcnia LKT w roztworze.

Zmiany w ilości aminokwasów oznac\%onych w jelicie ślepym w stosunku do ilości podanej były niewielkie z wyjątkiem kwasu asparaginowego i glutaminowego oraz treoniny i seryny, których ubytek był znaczący. Stężenie aminokwasów w roztworze nie wpływało istotnie na tempo ich wchłaniania. 